(C) Брижаченко Т.П., 2020

doi: 10.37321/nefrology.2021.28-05

УДК: 61-616.61

\title{
АСЕПТИЧНИЙ НЕКРОЗ ГОЛІВОК ОБОХ СТЕГНОВИХ КІСТОК У ПАЦІЄНТА З ГЛОМЕРУЛОНЕФРИТОМ НА ТЛІ ПРИЙОМУ ГЛЮКОКОРТИКОСТЕРОЇДІВ
}

\author{
БРИЖАЧЕНКО Т.П. \\ КНП «Київський міський центр нефрології та діалізу» \\ Київ, Україна
}

Резюме

\begin{abstract}
Вступ. Рідкісним ускладненням при прийомі глюкокортикоїдів $€$ аваскулярний некроз, механізм розвитку якого до кінця не з'ясований. Припускають, що ГК ушкоджують ендотеліальні клітини судин, призводячи до стазу, підвищення внутрішньокісткового тиску, знижують артеріальну перфузію, спричиняючи інфаркт кістки. Тривалий прийом глюкокортикоїдів асоціюється з розвитком різних побічних явищ. Однак аваскулярний некроз може виникнути і при короткочасному вживанні невисоких доз ГК. Знаючи про них, лікар може запобігти або мінімізувати цей негативний вплив.
\end{abstract}

Мета. Описати клінічний випадок асептичного некрозу голівок обох стегнових кісток у пацієнта з гломерулонефритом на тлі прийому глюкокортикостероїдів, проаналізувати динаміку лабораторно-інструментальних показників.

Матеріали і методи. Огляд сучасних та зарубіжних джерел, аналіз та обговорення конкретного клінічного випадку; методики - опис, аналіз, реферування.

Результати та їх обговорення. Частота виникнення асептичного некрозу кісток корелює з дозою і тривалістю прийому ГК. Відомо про його виникнення на тлі прийому глюкокортикоїдів у дозі більше 20 мг/добу, але частіше на більш високих дозах - 40 мг/добу. Однак аваскулярний некроз може виникнути і при короткочасному вживанні невисоких доз ГК. На ранніх стадіях симптоми неспецифічні: набряклість навколо ураженого суглоба й обмеження рухливості в ньому. Часто захворювання до певного моменту перебігає безсимптомно. Больовий синдром і кульгавість виникають на пізніх стадіях. Для діагностики цього ускладнення застосовують рентгенографію, MPT, KT.

Висновки. Прийом глюкокортикоїдів асоціюється 3 розвитком різних побічних явищ. Для раннього виявлення аваскулярного некрозу кісток лікар має ретельно обстежувати пацієнта при кожному відвідуванні, коригувати дози, тривалість та схеми призначення глюкокортикоїдів при гломерулонефриті.

Ключові слова: гломерулонефрит, глюкокортикоїди, нирки, некроз кісток.

Вступ. Глюкокортикоїди (ГК) - препарати, які широко застосовують у клінічній практиці. Рідкісним ускладненням при прийомі глюкокортикоїдів $€$ аваскулярний некроз, механізм розвитку якого до кінця не з'ясований. Припускають, що ГК ушкоджують ендотеліальні клітини судин, призводячи до стазу, підвищення внутрішньокісткового тиску, знижують артеріальну перфузію, спричиняючи інфаркт кістки. Тривалий прийом глюкокортикоїдів асоціюється з розвитком різних побічних явищ. Однак аваскулярний некроз може виникнути і при короткочасному вживанні невисоких доз ГК. Знаючи про них, лікар може запобігти або мінімізувати цей негативний вплив.

Мета. Описати клінічний випадок асептичного некрозу голівок обох стегнових кісток у паці- єнта з гломерулонефритом на тлі прийому глюкокортикостероїдів, проаналізувати динаміку лабораторно-інструментальних показників.

Матеріали і методи. Огляд сучасних та зарубіжних джерел, аналіз та обговорення конкретного клінічного випадку; методики - опис, аналіз, реферування.

Результати та їх обговорення. Наведено i проаналізовано конкретний клінічний випадок виникнення некрозу головки стегон з обох сторін.

Клінічний приклад (історія хвороби № 6932/20). Хворий М., 38 р., поступив до нефрологічного центру 01.09.2019 р. зі скаргами на загальну слабкість. Працює інженером.

3 анамнезу хвороби. Хворіє на гломерулонефрит з 05.11.2014р., лікувався високими доза- 
ми преднізолону. На тлі гормонотерапії виник некроз головки стегон з обох сторін. Цього ж року виявлена хронічна хвороба нирок - взятий на облік у КНП «КМЦ нефрології та діалізу»

Об'єктивно: загальний стан середньої тяжкості. Нормостенічна тілобудова, Положення у ліжку активне. Язик - вологий та чистий. Слизові оболонки та шкірні покриви - не змінені. Набряки - відсутні. Лімфатичні вузли - не збільшені. Набухання шийних вен та вен нижніх кінцівок - відсутнє. Тони серця - звучні. Присутній систолічний шум. Ритм серця - правильний. Межі серця - не змінені. Артеріальний тиск - 140/90 мм.рт. ст., пульс - 80уд./хв, ЧСС - 80уд./хв.
При поступленні поставлений діагноз: Хронічна хвороба 5Д стадії: гломерулонефрит, пролонгована сеансами ГД з 02.2019 р. Анемія. Артеріальна гіпертензія.

Кількість катетеризацій центральних вен: 1.

Кількість операцій формування а/в фістули (шунта): 1.

Судинний доступ на даний час: а/в фістула.

Переносимість гемодіалізу задовільна.

Ускладнення - гіпертонія.

Питний режим - дотримується.

Збільшення ваги між діалізами коливається від 1 до 3 кг. Суха вага 54 кг.

Ознаки гіпергідратації немає.

Динаміка показників загального аналізу крові хв-го М., 38р.

Таблиця 1

\begin{tabular}{|c|c|c|c|c|c|c|c|c|}
\hline \multirow{2}{*}{ Показник } & \multicolumn{8}{|c|}{ Дата (число, місяць) } \\
\hline & 03.02 & 05.08 & 03.09 & 01.10 & 17.11 & 09.01 & 11.01 & 04.02 \\
\hline Гемоглобін (HGB), г/л & 75 & 99 & 121 & 81 & 73 & 96 & 110 & 113 \\
\hline Гематокрит (НСТ), \% & 21,6 & & 36,8 & 23,1 & 20,7 & 27,9 & 31,2 & \\
\hline $\begin{array}{l}\text { Еритроцити (RBC, } \\
\text { x1012/л) }\end{array}$ & 2,50 & 3,17 & 3,89 & 2,58 & 2,20 & 3,05 & 3,69 & \\
\hline $\begin{array}{l}\text { Середній об'єм еритро- } \\
\text { цита (MCV), фл }\end{array}$ & 86,4 & 89,6 & 94,6 & 89,5 & 94 & 91,5 & 84 & \\
\hline $\begin{array}{l}\text { Середній вміст гемогло- } \\
\text { біну в еритроциті (МCH), } \\
\text { пг }\end{array}$ & 30,0 & 31,2 & 31,1 & 31,4 & 33 & 31,5 & 29,8 & \\
\hline $\begin{array}{l}\text { Середня концентрація } \\
\text { гемоглобіну в еритроциті } \\
\text { (МСНC), г/дп }\end{array}$ & 34,7 & 34,9 & 32,9 & 35,1 & 35,0 & 34,4 & 35,3 & \\
\hline $\begin{array}{l}\text { Ширина розподілення } \\
\text { еритроцитів (RDW-CD), } \\
\text { фп }\end{array}$ & 42,3 & 44,1 & 51,0 & 43 & 52,9 & 42,5 & 39,8 & \\
\hline $\begin{array}{l}\text { Ширина розподілення } \\
\text { еритроцитів (RDW-CV), } \\
\text { фп }\end{array}$ & 13,9 & 13,3 & 14,9 & 13,7 & 12,8 & 13,1 & 13,3 & \\
\hline $\begin{array}{l}\text { Тромбоцити (PLT), } \\
\text { (х109/л) }\end{array}$ & 235 & 253 & 276 & 201 & 224 & 163 & 313 & \\
\hline $\begin{array}{l}\text { Ширина розподілення } \\
\text { тромбоцитів за обсягами, } \\
\%\end{array}$ & 13,9 & 13,3 & 12,2 & 13,7 & & 14,6 & 10,3 & \\
\hline Тромбокрит, \% & 0,24 & 0,26 & 0,29 & 0,21 & & & 0,29 & \\
\hline $\begin{array}{l}\text { Середній об'єм тромбо- } \\
\text { цитів, фп }\end{array}$ & 10,4 & 10,4 & 10,4 & 10,6 & 9,4 & 11,7 & 9,1 & \\
\hline $\begin{array}{l}\text { Відношення числа вели- } \\
\text { ких тромбоцитів до за- } \\
\text { гального числа }\end{array}$ & 27,6 & & & 29,7 & & 39,7 & 18,3 & \\
\hline Лейкоцити (х109/л) & 2,50 & 4,91 & 6,88 & 9,17 & 6.35 & 4,65 & 6,59 & \\
\hline $\begin{array}{l}\text { Нейтрофіли, \% } \\
\text { Абс., (х109/л) }\end{array}$ & 66,7 & $\begin{array}{l}60,5 \\
2,97\end{array}$ & $\begin{array}{l}68,5 \\
4,71\end{array}$ & & $\begin{array}{l}75,0 \\
4,31 \\
\end{array}$ & & & \\
\hline $\begin{array}{l}\text { Еозинофіли, \% } \\
\text { Абс., (х109/л) }\end{array}$ & 5,3 & $\begin{array}{c}5,7 \\
0,28\end{array}$ & $\begin{array}{c}4,2 \\
0,29\end{array}$ & 2 & 0,14 & 1 & & \\
\hline $\begin{array}{l}\text { Базофіли, \% } \\
\text { Абс., (х109/л) }\end{array}$ & 0,3 & $\begin{array}{c}0,6 \\
0,03\end{array}$ & $\begin{array}{c}0,2 \\
0,05\end{array}$ & & 0,05 & & & \\
\hline Палочкоядерні, \% & 1 & & & 4 & & 1 & & \\
\hline
\end{tabular}




\begin{tabular}{|c|c|c|c|c|c|c|c|c|}
\hline \multirow{2}{*}{ Показник } & \multicolumn{8}{|c|}{ Дата (число, місяць) } \\
\hline & 03.02 & 05.08 & 03.09 & 01.10 & 17.11 & 09.01 & 11.01 & 04.02 \\
\hline Сегментоядерні, \% & 66 & & & 81 & & 72 & & \\
\hline $\begin{array}{l}\text { Лімфоцити, \% } \\
\text { Абс. (х10\%/л) }\end{array}$ & 18 & $\begin{array}{c}24,2 \\
1,9\end{array}$ & $\begin{array}{l}18,5 \\
1.27\end{array}$ & 8 & & 17 & & \\
\hline $\begin{array}{l}\text { Моноцити, \% } \\
\text { Абс. }\end{array}$ & $\begin{array}{c}10 \\
0,44\end{array}$ & & $\begin{array}{l}8,1 \\
0,58 \\
\end{array}$ & 5,2 & 0,48 & 9 & & \\
\hline ШОЕ, мм/год & 26 & 24 & 27 & 26 & & & & \\
\hline
\end{tabular}

Динаміка показників біохімічного аналізу крові хв-го М., 38 р.

Таблиця 2

\begin{tabular}{|c|c|c|c|c|c|}
\hline \multirow{2}{*}{ Показник } & \multicolumn{5}{|c|}{ Дата (число, місяць) } \\
\hline & 05.08 & 03.09 & 11.01 & 03.02 & 08.02 \\
\hline Глюкоза, ммоль/л & 5,52 & & 5,4 & & 8,5 \\
\hline Альфа-амілаза, од/л & & & 113 & & 112 \\
\hline Сечовина, ммоль/л & & 11 & 22,3 & 5,9 & 6,4 \\
\hline Креатинін, мкмоль,л & & 538 & 747 & 200 & 206 \\
\hline $\begin{array}{l}\text { Білірубін загальний, } \\
\text { ммоль/л }\end{array}$ & & 5,1 & 8,2 & 10,5 & 9,7 \\
\hline Прямий & & 2 & & 0 & \\
\hline Непрямий & & 3,1 & & 10,5 & \\
\hline АлТ, од/л & 10 & 7 & 23 & 0,4 & 3 \\
\hline АсТ, од/л & 10 & 8 & 11 & 0,2 & 16 \\
\hline ГГТ, од/л & 26 & 19 & 74 & & \\
\hline Лужна фосфатаза, од/л & 63 & 74 & 105 & & 95 \\
\hline КФК, од/л & & & 28 & & 244 \\
\hline КФК-МВ, од/л & & & 12,7 & & 9,2 \\
\hline ЛДГ, од/л & & & 186 & & 198 \\
\hline Загальний білок, г/л & 75,3 & 83 & 82,8 & 77 & \\
\hline Альбумін, \% & 60,69 & 51,5 & 45,1 & & 41,6 \\
\hline Глобулін, \% & 39,31 & & & & \\
\hline А/Г коефіцієнт & 1,54 & & & & \\
\hline Сечова к-та, мкмоль/л & & 186 & 361 & & 80 \\
\hline Холестерин, ммоль/л & & 3,46 & 3,13 & & 3,51 \\
\hline Тригліцериди, ммоль/л & & 1,61 & 1,54 & & 1,89 \\
\hline ЛПВШ, ммоль/л & & 0,91 & 1,54 & & 0,88 \\
\hline ЛПНЩ, ммоль/л & & 1,76 & 0,92 & & 1,77 \\
\hline ЛПДНЩ, ммоль/л & 0,79 & & 0,7 & & 0,86 \\
\hline $\begin{array}{l}\text { Коефіцієнт атероген- } \\
\text { ності }\end{array}$ & 2,8 & & & & 2,99 \\
\hline калій, ммоль/л & 5,06 & 5,83 & 5,3 & & \\
\hline $\begin{array}{l}\text { Натрій (сиворотка), } \\
\text { ммоль/л }\end{array}$ & 139 & 140 & 131 & & \\
\hline фосфор, ммоль/л & 2,33 & 1,46 & 1,28 & & \\
\hline Кальцій, ммоль/л & & & 2,97 & & \\
\hline Магній, ммоль/л & & & 0,79 & & \\
\hline Трансферин & & & 1,95 & & \\
\hline Феритин, мкг/л & & & 1554,9 & & \\
\hline $\begin{array}{l}\text { Насичення трансфери- } \\
\text { на залізом, \% }\end{array}$ & & & 35,38 & & \\
\hline
\end{tabular}


5.08.2020 р. Біохімічний аналіз крові: вірус гепатиту C - 0,039, індекс, вірус гепатиту B - 0,321 COI, Treponema pallidum - 0,08 COI.

5.08.2020 р. Біохімічний аналіз крові: ПЛР Цитомегаловірус - не виявлений, ПЛР вірус Епштейна-Барр - не виявлений, група крові - 2_A(II), резус-фактор - Rh (+) позитивний.

\section{МІСЯЧНИЙ ЕПІКРИЗ ЗА СІЧЕНЬ 2020 РОКУ.}

Хворий М-ко А.С. лікується діалізом 10 місяців. 3 них ГД 10 місяців.

Судинний доступ: А-В фістула. Локалізація: н/3 лівого передпліччя.

Стан судинного доступу задовільний.

Діалізний індекс: eKt/V: 1,2.

Діалізний час: 12 годин/тиждень; Кількість ГД на тиждень: 3;

Переносимість діалізу задовільна.

Ускладнення: АГ, анемія.

Питний режим: дотримується. Добовий діурез: 400 мл/добу.

Міждіалізний приріст ваги від 1 до 3 кг. «Суха вага»: 54 кг.

Скарги на загальну слабкість.

$\mathrm{Coн} \mathrm{не} \mathrm{порушений.} \mathrm{Апетит} \mathrm{збережений.}$

Коливання ваги тіла за місяць: прибавка на 1,2 кг.

Ознаки гіпергідратації: немає.

Ознаки серцевої недостатності: немає.

Гіпертрофія лівого шлуночка: незначна.

Гіпертензія: $€$.

Ознаки перикардиту: немає.

Ознаки гідротораксу: немає.

Ознаки нейропатії: немає.

Ознаки порушень кісткового та мінерального обміну: немає.

Запалення: немає.

Анемія: незначна, гемоглобін 83 г/л.

Гемотрансфузії: не проводились.

Еритропоетин: не отримував.

\section{Рекомендований режим 3НТ:}

Діалізатор вибору 20 DS 18; діалізатор резерву 20 DS 20.

«Суха вага»: 54 кг; Діалізний час: 12 годин/тиждень.

Кількість ГД на тиждень: 3.

Швидкість кровотоку: 240. Натрій діалізату: 136. Температура діалізату: 37. Бікарбонат діалізату: 2,9.

Антикоагулянт: фраксипарин; доза: 0,4.

Рекомендоване медикаментозне лікування (згідно листа призначень).

3.02.2020. Ендокринне дослідження крові: паратгормон - 34.77 пг/мл, тиреотропний гормон - 2.95мкMO/мл
18.02.2020. Аналіз на сифіліс та гепатит: результат на наявінсть Syphilis TP негативний, результат на наявність $\mathrm{HBsAg}-0.22$, результат на наявність Anti HCV - негативний, результат на наявінсть HIV Ag/Ab - негативний

\section{МІСЯЧНИЙ ЕПІКРИЗ ЗА КВІТЕНЬ 2020 РОКУ.}

Хворий М-ко А.С. лікується діалізом 13 місяців.

Судинний доступ: А-В фістула.

Діалізний індекс eKt/V: 1,2.

Діалізний час: 4 годин/тиждень; Кількість процедур на тиждень: 3;

Переносимість діалізу задовільна.

Ускладнень немає.

Питний режим: дотримується. Добовий діурез: 150 мл/добу.

Міждіалізний приріст ваги від 1 до 2 кг. «Суха вага»: 60 кг.

Скарги на загальну слабкість, головокружіння.

Коливання АТ від 180/90 мм рт.ст. до 140/90 мм рт.ст. Пульс 78 уд/хв.

Еритропоетин: отримував.

Супутнє лікування: дієтичні рекомендації.

Рекомендується наступний режим діалізів: "суха вага» 60 кг.

Діалізний час: 4 години/тиждень.

Кількість процедур на тиждень: 3.

Діалізатор вибору 40 DS 18; діалізатор резервy 40 DS 21.

Швидкість кровотоку: 500.

Натрій діалізату: 131.

Температура діалізату: 36,7.

Антикоагулянт: гепарин; доза: 10000 ОД.

Рекомендоване медикаментозне лікування (за листом призначень).

3.09.2020. Біохімічний аналіз крові: вірус гепатиту В - не виявлений,

17.11.2020p. Розгорнутий аналіз крові: ТР - 82.7g/l, BILTot - 10.9umol/l, BILDir - 4.3umol/l, BiLN - 6.6umol/I, ALT - 8.8U/L, AST - 8.2U/L, Urea $-21.9 \mathrm{mmol} / \mathrm{L}$, Creat $-1035 \mathrm{umol} / \mathrm{L}$, ALB $-54.5 \mathrm{~g} / \mathrm{L}$, Glu $-5.9 \mathrm{mmol} / \mathrm{L}$

17.11.2020p Загальний аналіз крові: Urea $9.7 \mathrm{mmol} / \mathrm{L}$, Creat $-351-$ umol$/ \mathrm{L}$

\section{МІСЯЧНИЙ ЕПІКРИЗ ЗА ЛИСТОПАД 2020Р.}

Хворий М-ко А.С. лікується діалізом 19 місяців.

Судинний доступ: А-В фістула. локація н/3 лівого передпліччя.

Стан судинного доступу задовільний.

Діалізний індекс eKt/V: 1,2.

Діалізний час: 12 годин/тиждень;

Переносимість діалізу задовільна.

Ускладнень немає. 
Питний режим: дотримується. Добовий діурез: 100 мл/добу.

Міждіалізний приріст ваги від 1 до 2 кг. «Суха вага»: $60 \mathrm{kr.}$

Скарги на загальну слабкість, головокружіння, стрибки АТ. Слабкість після навантаження.

Сон не порушений. Апетит збережений.

Коливання ваги тіла за місяць: втрата ваги на 0 кг, прибавка на кг.

Ознаки гіпергідратації немає.

Ознаки серцевої недостатності $€$ :

Гіпертрофія лівого шлуночка помірна.

Гіпертензія: $\epsilon$, ступінь 3, коливання АТ від 170/100 до 130/80 мм рт.ст., коригується УФ та медикаментозно.

Ознак перикардиту, гідротораксу, нейропатії, порушень кісткового та мінерального обміну, запалення немає.

Анемія незначна.

Гемотрансфузії не проводились.

Еритропоетин: не отримував.

Рекомендований режим 3НТ: «суха вага» 60кг. Діалізний час 12 год/тижд.; Кількість ГД на тиждень: 3; Швидкість кровотоку: 500. Натрій діалізату: 136. Температура діалізату: 36,7. Бікарбонат діалізату: 3,1. Антикоагулянт: гепарин 10.000 ОД.

\section{Рекомендоване медикаментозне лікування:}

1. Сорбіфер 1т. 1 раз на добу.

2. Леркамен 10 мг 1 раз на добу.

3. Небімаг 5мл 1 раз на добу.

20.12.2020 Ендокринне дослідження крові: паратгормон (1-84) - 28.1пг/мл

\section{МІСЯЧНИЙ ЕПІКРИЗ ЗА ГРУДЕНЬ 2020Р.} ців.

Хворий М-ко А.С. лікується діалізом 20 міся-

Судинний доступ: А-В фістула. Локація н/3 лівого передпліччя.

Стан судинного доступу задовільний.

Діалізний індекс еKt/V: 1,2.

Діалізний час: 12 годин/тиждень; Кількість ГД на тиждень: 3.

Переносимість діалізу задовільна.

Ускладнень немає.

Питний режим: дотримується. Добовий діурез: 100 мл/добу.

Міждіалізний приріст ваги від 1 до 2 кг. «Суха вага»: 60 кг.

Скарги на загальну слабкість, головокружіння, стрибки АТ до 170/100 мм рт.ст. Слабкість після навантаження.

Сон не порушений. Апетит збережений.

Коливання ваги тіла за місяць: втрата ваги на 0 кг, прибавка на кг.

Ознаки гіпергідратації немає.

Ознаки серцевої недостатності є:
Гіпертрофія лівого шлуночка помірна.

Гіпертензія: $\epsilon$, ступінь 3, коливання АТ від 170/100 до 130/80 мм рт.ст., коригується УФ та медикаментозно.

Ознак перикардиту, гідротораксу, нейропатії, порушень кісткового та мінерального обміну, запалення немає.

Анемія незначна.

Гемотрансфузії не проводились.

Еритропоетин не отримував.

Рекомендований режим 3НT: "суха вага" 60кг. Діалізний час 12 год/тижд.; Кількість ГД на тиждень: 3; Швидкість кровотоку: 500. Натрій діалізату: 136. Температура діалізату: 36,7. Бікарбонат діалізату: 3,1. Антикоагулянт: гепарин 10.000 ОД.

\section{Рекомендоване медикаментозне лікування:}

1. Сорбіфер 2т. 1 раз на добу.

2. Леркамен 10 мг 1 раз на добу.

09.01.2021 Розгорнутий аналіз крові: АЛТ $20 \mathrm{MO} / л$, АСТ - 15 МО/л, білірубін загальний - 7,2 ммоль/л, сечовина - 31.8ммоль/л, креатинін 896ммоль/л, загальний білок - 62.3 г/л, альбумін - 38.5 г/л, глюкоза 5.8 ммоль/л, альфа амілаза - 103 МО/л, фосфатаза лужна - 117 МO/л, гамма-ГТ - 19 МО/л, КФК - 140 MO/л, КФК-МВ - $20.3 \mathrm{MO} / л$, лДГ - 123 МО/л, сечова кислота - 400 ммоль/л, холестерин загальний 2.08 ммоль/л, тригліцериди - 1,23 ммоль/л, холестерин ЛПВЩ - 0.70 ммоль/л, холестерин ЛПНЩ - 0.82 ммоль/л, холестерин ЛПДНЩ - 0.56 ммоль/л, Хзаг-Хлпвщ-Хлпвщ - 1.97, Са -3.90 ммоль/л, Mg - 0.75 ммоль/л, $\mathrm{P}-0.85$ ммоль/л, $\mathrm{Fe}-10.7$ ммоль/л, $\mathrm{K}$ - 4.9 ммоль/л, $\mathrm{Na}-128$ ммоль/л

Обговорення. Патогенетична терапія хронічного гломерулонефриту (нефротичний синдром, хронічний нефритичний синдром) відрізняється в залежності від морфологічного варіанту гломерулонефриту, тому правомочна тільки після проведення біопсії нирки, верифікації морфологічного діагнозу і повинна тривати в амбулаторних умовах. Лікування дебюту гломерулонефриту передбачає призначення метилпреднізолону у дозі 0,6-0,8мг/кг/добу або преднізолону 0,5-1мг/ кг/добу (максимальні добові дози 64 і 80мг, відповідно) впродовж 6-8 тижнів (краще тривале призначення до 12-16 тижнів) у вигляді одноразової дози в ранковий час, після прийому сніданку (Рівень 1В). По досягненню повної або часткової ремісії - зниження дози преднізолону на 5 мг кожні 3-4 дні до досягнення дози преднізолону 20-30мг/добу. Наступні 2-3 місяці прийом пред- 
нізолону в альтернуючому режимі, тобто через день з поступовим зниженням дози по 5 мг кожні 1-2 тижні, до досягнення 10мг (Рівень 2В). Подальше зниження дози по 2,5 мг кожні 1-2 тижні при альтернуючій схемі прийому до повного скасування. Більш швидке зниження дози преднізолону можливо при появі небажаних явищ стероїдної терапії. Пацієнти, які не досягли повної або часткової ремісії після прийому повної дози протягом 16 тижнів, визначаються як стероїдрезистентні та вимагають комбінованої терапії циклоспорином-А та мінімальною дозою преднізолону 0,15-0,2мг/кг/добу. Ритуксимаб використовується для лікування різних морфологічних варіантів НC при відсутності ефекту від вище проведеної терапії. Призначається в дозі 375мг/ м2 поверхні тіла, 1 раз в тиждень, всього №4, внутрішньовенно, крапельно після премедикації. При стероїд-резистентності рекомендується проведення повторної біопсії (так як не виключається трансформація в ФСГС).

Ризик виникнення аваскулярного некрозу підвищується в разі зловживання алкоголем, наявності антифосфоліпідних антитіл, при подагрі тощо. Частота його розвитку також корелює з дозою і тривалістю прийому ГК. Так, в одному проспективному дослідженні всі пацієнти, у яких розвинувся аваскулярний некроз, отримували глюкокортикоїди у дозі більше 20 мг/добу, у 93\% з них доза була вищою - 40 мг/добу. Однак аваскулярний некроз може виникнути і при короткочасному вживанні невисоких доз ГК. На ранніх стадіях симптоми неспецифічні: набряклість навколо ураженого суглоба й обмеження рухливості в ньому. Часто захворювання до певного моменту перебігає безсимптомно. Больовий синдром і кульгавість виникають на пізніх стадіях. Для діагностики цього ускладнення застосовують рентгенографію, МРТ, КТ. Терапія включає ліжковий режим, розвантаження ушкодженої кінцівки, застосування нестероїдних протизапальних засобів (НПЗ3) або інших препаратів для усунення больового синдрому. Надалі часто рекомендоване хірургічне лікування (заміна суглоба).

Таким чином, прийом глюкокортикоїдів асоціюється з розвитком різних побічних явищ. Для раннього виявлення аваскулярного некрозу кісток лікар має ретельно обстежувати пацієнта при кожному відвідуванні, аби не пропустити наявності обмеження руху в суглобах, припухлості, больового синдрому, коригувати дози, тривалість та схеми призначення глюкокортикоїдів при гломерулонефриті.

\section{ЛITEPATУPA}

1. Хронічна хвороба нирок / Внутрішні хвороби. Підручник заснований на принципах доказової медицини 2018/2019. С. 957-966.

\section{PEЗЮME \\ АСЕПТИЧЕСКИЙ НЕКРОЗ ГОЛОВОК ОБЕИХ БЕДРЕННЫХ КОСТЕЙ У ПАЦИЕНТОВ С ГЛОМЕРУЛОНЕФРИТОМ НА ФОНЕ ПРИЕМА ГЛЮКОКОРТИКОСТЕРОИДОВ}

Брижаченко Т.П.

КНП «Киевский городской центр нефрологии и диализа» (Киев, Украина)

Введение. Редким осложнением при приеме глюкокортикоидов является аваскулярный некроз, механизм развития которого до конца не выяснен. Предполагают, что ГК повреждают эндотелиальные клетки сосудов, приводя к стазу, повышение внутрикостного давления, снижают артериальную перфузию, вызывая инфаркт кости. Длительный прием глюкокортикоидов ассоциируется с развитием различных побочных явлений. Однако аваскулярный некроз может возникнуть и при кратковременном употреблении невысоких доз ГК. Зная о них, врач может предотвратить или минимизировать это негативное влияние.

Цель. Описать клинический случай асептического некроза головок обеих бедренных костей у пациента с гломерулонефритом на фоне приема ГКС, проанализировать динамику лабораторно-инструментальных показателей.

Материалы и методы. Обзор современных и зарубежных источников, анализ и обсуждение конкретного клинического случая; методики - описание, анализ, реферирование.

Результаты и их обсуждение. Частота возникновения асептического некроза костей коррелирует с дозой и длительностью приема ГК. Известно о его возникновении на фоне приема глюкокортикоидов в дозе более 20 мг/сут., но чаще на более высоких дозах - 40 мг/сут. Однако аваскулярный некроз может возникнуть и при кратковременном употреблении невысоких доз ГК. На ранних стадиях симптомы неспецифические: отечность вокруг пораженного сустава и ограничение подвижности в нем. Часто заболевание до определенного момента протекает бессимптомно. Болевой синдром и хромота возникают на поздних стадиях. Для диагностики этого осложнения применяют рентгенографию, МРТ, КТ.

Выводы. Прием глюкокортикоидов ассоциируется с развитием различных побочных явлений. Для раннего выявления аваскулярного некроза костей врач должен тщательно обследовать пациента при каждом посещении, корректировать дозы, длительность и схемы назначения глюкокортикоидов при гломерулонефрите.

Ключевые слова: гломерулонефрит, глюкокортикоиды, почки, некроз костей. 


\section{SUMMARY}

\section{ASEPTIC NECROSIS OF THE HEADS OF BOTH FEMURS IN PATIENTS WITH GLOMERULONEPHRITIS ON THE BACKGROUND OF GLUCOCORTICOSTEROIDS}

Bryzhachenko T.P.

KNP "Kyiv City Center of Nephrology and Dialysis" (Kyiv, Ukraine)

Introduction. A rare complication of glucocorticoids is avascular necrosis, the mechanism of development of which is not fully understood. GC is thought to damage vascular endothelial cells, leading to stasis, increased intraosseous pressure, and reduced arterial perfusion, causing bone infarction. Prolonged use of glucocorticoids is associated with the development of various side effects. However, avascular necrosis can also occur with short-term use of low doses of HA. Knowing about them, the doctor can prevent or minimize this negative impact.

Goal. To describe a clinical case of aseptic necrosis of the heads of both femurs in a patient with glomerulonephritis on the background of corticosteroids, to analyze the dynamics of laboratory and instrumental parameters.
Materials and methods. Review of modern and foreign sources, analysis and discussion of a specific clinical case; methods - description, analysis, abstracting.

Results and discussion. The incidence of aseptic bone necrosis correlates with the dose and duration of $\mathrm{HA}$. It is known to occur on the background of glucocorticoids at a dose of more than $20 \mathrm{mg} /$ day, but more often at higher doses - $40 \mathrm{mg} /$ day. However, avascular necrosis can also occur with short-term use of low doses of HA. In the early stages, the symptoms are nonspecific: swelling around the affected joint and limited mobility in it. Often the disease is asymptomatic until a certain point. Pain and lameness occur in the late stages. To diagnose this complication, radiography, MRI, CT are used.

Conclusions. Glucocorticoids are associated with the development of various side effects. For early detection of avascular necrosis of the bone, the doctor should carefully examine the patient at each visit, adjust the dose, duration and schedule of glucocorticoids in glomerulonephritis.

Key words: glomerulonephritis, glucocorticoids, kidneys, bone necrosis.

\section{АВТОРСЬКА ДОВІДКА}

\section{Брижаченко Тетяна}

\section{Павлівна}

КНП «Київський міський центр нефрології та діалізу», м. Київ

Адреса: вулиця Петра Запорожця, 26, Київ, 02125

моб.: +380679361823

E-mail: moyseyenko_vo@ukr.net

\section{Брижаченко Татьяна Павловна}

КНП «Киевский городской центр нефрологии и диализа», г. Киев Адрес: ул. Петра Запорожца, 26, Киев, 02125

моб.: +380679361823

E-mail: moyseyenko_vo@ukr.net

\section{Bryzhachenko Tetyana}

KNP "Kyiv City Center of Nephrology and Dialysis", Kyiv

Address: 26 Petro Zaporozhets Street, Kyiv, 02125

mob.: +380679361823

E-mail: moyseyenko_vo@ukr.net

Стаття надійшла до редакції 3.02.21 p. 